Insight, part of a Special Feature on The Privilege to Fish

\title{
Changing U.S. Ocean Policy Can Set a New Direction for Marine Resource Management
}

\author{
Andrew A. Rosenberg ${ }^{1}$
}

\begin{abstract}
A central concept in a new direction for ocean policy in the United States is ecosystem-based management, that is, implementation of management integrated across sectors of human activity to achieve the common goal of conserving the structure and function of marine ecosystems to provide a full suite of ecosystem services. Fisheries are a critical sector of ocean activity that impacts these ecosystems, and fishery management is in urgent need of reform to perform better from a conservation perspective. Here, I suggest some specific changes in perspective for fishery management as part of an overall ecosystembased approach.
\end{abstract}

Key Words: fishery management; marine conservation; ocean policy

From the perspectives of fishermen, policy makers, and public interest groups, fisheries in the United States and around the world are in trouble in many ways. Without a doubt, many fishery resources have been overexploited and depleted, critical habitat has been lost, and current practices continue to be unsustainable (Christensen et al. 2003, NRC 2006, FAO 2007). However, not all fisheries are in collapse, and recovery is not impossible (Garcia and Grainger 2005, Rosenberg et al. 2006, Beddington et al. 2007). Fishermen have seen an increase in costs, regulation, and competition, and a reduction in business flexibility, along with shrinking resources, and they have been pressured by increasing public concern for the source, sustainability, and environmental impact of the seafood they purchase. Policy makers have been under pressure to find solutions to conservation problems while maintaining employment, responding to backlash against regulatory controls, providing economic opportunity, and catching up to the endless and creative innovation in the industry for harvesting fish. Public interest advocates, such as environmental groups, struggle for attention on conservation issues, such as fishing, with a public that is only vaguely aware of issues and that has a tendency to focus on the charismatic rather than the technical, as well as with industrial and sometimes governmental perspectives in which environmental interests are not compatible with fishing interests.
Overexploitation and depletion of fisheries have real consequences, from the loss of food security and economic opportunity for coastal communities to the loss of resources held in the public trust (Turnipseed et al. 2009) and the loss of ecosystem function for the marine ecosystems that are a vital link for the ecosystem services that support human well-being (Millennium Ecosystem Assessment 2005). It is fair to ask why overexploitation is allowed to occur, and indeed allowed to continue, in many fisheries around the world, even in highly developed regions. Surely we have the knowledge and governmental capacity to control fishing in exclusive economic zones of coastal states. The problem is often political, and not a matter of technical knowledge (Rosenberg 2003, 2007). Political resistance to regulation is endemic in most societies, and although technical expertise may be available and sufficient to prevent or end overexploitation, the political will to do so is difficult to come by. This is, in turn, frequently because fisheries management issues are most often dealt with as more in the realm of constituent services than as public policy. That is, elected officials respond to the constituents who are directly engaged in fisheries issues, i.e., the fishing industry, for the most part, rather than responding to the broader policy need. Most of the public is uninformed about fisheries management issueseven if they in fact care where their seafood comes 
from!- - and certainly are not engaged in the often arcane details of management. That means, the broader public is not engaging elected officials on these issues, but the recreational and commercial industry certainly is. To be sure, in the last decade or so, public interest groups have also engaged in the process of management, but the dominant political interest is still from the perspective of industry and almost universally against greater regulation. As a former federal fishery official in the United States, I often received letters, calls, or communications from elected officials, but never was I urged to take stronger, more conservative, or more restrictive management actions for domestic fisheries.

Recent ocean policy initiatives in the United States, including the reports of two national commissions on ocean policy (Pew Oceans Commission 2004, U. S. Commission on Ocean Policy 2004), followed by some changes in the laws governing marine resource use (e.g., NOAA 2007), provide an opportunity to make some fundamental changes in the way marine resources are managed. As a central feature of a new direction in ocean policy, these commissions recommended moving beyond the model of managing each sector of human activity separate and apart from each other as if there were no cumulative impacts or interactions between, say, fisheries and coastal development or water quality management. Instead, the commissions called for an integrated, ecosystem-based approach to management (McLeod et al 2005), that is, managing all of the human activities impacting an ecosystem in concert and explicitly stating goals for maintaining ecosystem services (see, for example, Rosenberg and McLeod 2005). Setting a common goal across sectors of conserving the structure and function of an ecosystem is a critical step in adopting this new policy approach. The concept of ecosystem-based management underlies some recent policy initiatives including the California Ocean Protection Act (California Ocean Protection Council 2004) and a new law in Massachusetts to develop a comprehensive ocean management plan for state waters (Massachusetts Office of Coastal Zone Management 2008). The intention is to move beyond the sector-by-sector approach and begin planning for ocean ecosystems as a whole.

It is noteworthy that some states have taken a leading role in implementing ecosystem-based management of the coastal ocean. To be sure, states have always had major roles and responsibility for coastal policy, but usually based on federal statutes such as the Coastal Zone Management Act. Now, integrated policy is being mandated from state government for the coastal zone out to three miles $(4.8 \mathrm{~km})$. Hopefully, the federal authority will catch up, but as yet, Congress has not passed a mandate to integrate management for the public trust resources from 3 to 200 miles ( 4.8 to $322 \mathrm{~km}$ ).

For fisheries, the integration of management is a profound change. As noted above in the discussion of political forces that affect fishery management decisions, fisheries policy has existed in something of an insular world, as if the decisions made for fisheries have no effect on other activities or parts of society. Nevertheless, decisions on other activities that might affect the productivity of fish stocks such as habitat loss, or access to coastal space by fishermen certainly affect the viability of commercial and recreational fisheries. The prospect of planning comprehensively for ocean uses, with explicit goals to maintain ecosystem services, is a new direction that may change the tenor and shape of fishery policy, not least because it opens up that insular world and has the prospect of changing the political dynamics of management discussions.

The implementation of an ecosystem-based approach to management does not mean that the fundamentals of fishery management are no longer necessary. It will always be important to prevent overfishing of individual stocks, reduce bycatch of unwanted species, prevent destructive fishing practices, and ensure that no illegal, unregulated, or unlicensed fishing occurs. Even though broader ecosystem considerations are important, basic fishery controls must be in place for more than just highly marketable target species. Indeed, the failures of fishery management that have resulted in resources losses are often attributable to simple overfishing of individual stocks (Rosenberg et al. 2006). For any fishery, the proximate problem is to control fishing pressure to sustain the resource. Then, secondary effects, such as complex environmental and ecological interactions, must be considered beyond just the control of fishing.

Beyond the political issues, a critical problem in fisheries management is that the incentive structure for the industry is often misaligned with conservation and management needs. From a simplistic perspective, it is clearly advantageous for fishermen, both recreational and commercial, to have a sustainable resource base to depend upon. 
However, unless fishing capacity is strictly limited to a level reasonably matched to the productivity of a given ecosystem, then stability is very difficult to come by because of competition for fishing opportunity and catch. If the number and capacity of fishing vessels in the fleet are very large, then any incentive to conserve by a vessel can be immediately undermined by another in a variation on the well-known theme of the "tragedy of the commons." Many fishery management systems have an inherent incentive for fishermen to push the rules as far as possible to maximize catch. This, in turn, means that fishermen will always innovate to increase fishing power. Managers are then in a position of trying to innovate the regulations so that they can keep up with industry changes, but of course they can never quite catch up. The result is what Poul Degnbol, Directorate-General for Fisheries and Maritime Affairs of the European Commission, refers to as the "death spiral" of fisheries, with micromanagement of fishing operations attempting to control fishing pressure on resources in a never-ending game of catch-me-ifyou-can.

Conventional fisheries management tends to implement management tactics with relatively little feedback to either fishermen or managers with regard to the effectiveness of a given plan for conservation. Oddly, the development of a management plan is often based on conservation needs, e.g., ending overfishing, but the implementation and operation of the plan do not make participants or managers accountable for ensuring that management measures work as intended. It is as if the plan is the requirement, and not conservation, and then the battle continues when the conservation goals are not met. In addition, broad-scale measures, e.g., overall catch quotas, are usually the prime content of a plan, but fisheries are far from uniform in space or across fleets. Although overall controls are needed, if they are not further elaborated by area, fleet, or vessel, then they may be quite ineffective because there is little incentive to comply.

To find an alternative, the incentive structure must change to one that favors stability over pushing the rules to the limit with fishing tactics and increasing fishing power. Such an alternative incentive structure should, in my view, have the following features so that the dynamics of fishery management can be changed toward conservation:
1. The privilege to fish must be strictly linked to conservation performance. This must be the case for both recreational and commercial fisheries. Fishery resources are held in the public trust. If conservation and management measures are enacted, then any access to resources must be conditioned upon full compliance with those measures.

2. The goal should be the stability of fisheries, not maximizing production. Although the stability of catches is not a new idea in fisheries, it has often been thought of in terms of fleet-wide catches. For a fisherman, it is vessel-catch stability that might be more compelling with regard to business planning, or for a cooperative, the stability of catch for that group of vessels.

3. Accountability for conservation results must be part of management. Too often, plans are written, but the end result is far from the planned result, and there are no consequences. Such a system cannot work effectively.

4. The rules and conditions for the fishery must be consistent. When fisheries are micromanaged as discussed above, the rules change very frequently. An incentive to work within conservation restrictions might be some assurance that regulations will remain constant for a fixed period before adjustment, much like safe-harbor plans for landowners to protect endangered species.

5. Area-based management should be implemented, with privileges defined for a specific area for each vessel. This is a refinement of limited access systems that will improve predictability for fishermen because it limits the movement of new vessels into an area. As part of areabased management, if fishing capacity is well matched to productivity, then greater flexibility for fishermen can be allowed between fisheries within the area to adjust for market and environmental variability among years.

Although all of these changes are a departure from current management practice, they still use some of the tools of fishery management. They all depend upon capacity management as a starting point as 
well. It should be recognized that social goals related to coastal community sustainability, employment, small business viability, and economic return are not necessarily undermined by changing incentive structure. Of course, improving the sustainability of the resource is fundamental for all of these social goals, but so may be improving the stability and resilience of fisheries.

Finally, the concept of area-based management naturally dovetails with ecosystem-based management if area management is not just for the fishery resources. Because policy makers consider all of the human activities within an area as well as the ecosystem services that are provided within that area, then planning for a compatible mix of activities can become explicit rather than an implicit political battle.

Fisheries governance (Sissenwine and Mace 2003) is changing slowly. More can be done, and more quickly, but those changes have to modify the structure of fishery policy and the fishing industry if they are to prove effective.

Responses to this article can be read online at:

http://www.ecologyandsociety.org/voll4/iss2/art6/responses/

\section{Acknowledgments:}

I acknowledge Dr. Mimi Lam and Ms. Rachel Strader for organizing the symposium on "The Privilege to Fish" at the AAAS meeting in Boston that motivated this paper.

\section{LITERATURE CITED}

Beddington, J. R., D. J. Agnew, and C. W. Clark. 2007. Current problems in the management of marine fisheries. Science 316:1713-1716.

California Ocean Protection Council. 2004. California Ocean Protection Act. Available online at: http://www.opc.ca.gov/webmaster/ftp/pdf/docs/ Documents Page/Noteworthy/COPA\%202009.pdf

Christensen, V., S. Guénette, J. J. Heymans, C. J. Walters, R. Watson, D. Zeller, and D. Pauly. 2003. Hundred-year decline of North Atlantic predatory fishes. Fish and Fisheries 4:1-24.

FAO. 2007. The state of world fisheries and aquaculture. FAO, Rome, Italy. Available online at: http://www.fao.org/docrep/011/i0250e/i0250e00. $\underline{\mathrm{htm}}$.

Garcia, S. M., and R. J. R. Grainger. 2005. Gloom and doom? The future of marine capture fisheries. Philosphical Transactions of the Royal Society Series B 360:21-46.

Massachusetts Office of Coastal Zone Management. 2008. Massachusetts Oceans Act. Available online at: http://www.mass.gov/legis/laws/seslaw08/s1080114. htm.

http://www.mass.gov/czm/oceanmanagement/oceans act/ index.htm.

McLeod, K. L., J. Lubchenco, S. R. Palumbi, and A. A. Rosenberg. 2005. Scientific consensus statement on marine ecosystem-based management. The Communication Partnership for Science and the Sea. Available online at: http://www.compasso nline.org/pdf files/EBM Consensus Statement v12. pdf.

Millennium Ecosystem Assessment. 2005. Ecosystems and human well-being: synthesis. Island Press, Washington, D.C., USA. Available online at: http://www.maweb.org/documents/docum ent.356.aspx.pdf.

Myers, R. A., and B. Worm. 2003. Rapid worldwide depletion of predatory fish communities. Nature 423: 280-283.

National Oceanic and Atmospheric Administration (NOAA). 2007. Magnuson-Stevens Fishery Conservation and Management Act, as amended through January 12, 2007. U.S. Department of Commerce, Washington, D.C., USA.

National Research Council (NRC). 2006. Dynamic changes in marine ecosystems: fishing, food webs and future options. National Academies Press, Washington, D.C., USA.

Pew Oceans Commission (POC). 2003. America's living oceans: charting a course for sea change. POC, Arlington, Vermont, USA. Available online at: http://http://www.pewtrusts.org/our work repo rt detail.aspx?id=30009.

Rosenberg, A. A. 2003. Managing to the margins: 
the overexploitation of fisheries. Frontiers in Ecology and the Environment 1:102-106.

Rosenberg, A. A. 2007. Fishing for certainty: an essay on science and politics. Nature 449:989.

Rosenberg, A. A., and K. L. McLeod. 2005. Implementing ecosystem-based approaches to management for the conservation of ecosystem services. Marine Ecology Progress Series 300:270-274.

Rosenberg, A. A., J. H. Swasey, and M. Bowman. 2006. Rebuilding U.S. fisheries: progress and problems. Frontiers in Ecology and the Environment 4:303-308.

Sissenwine, M. P., and P. M. Mace. 2003. Governance for responsible fisheries: an ecosystem approach. Pages 363-392 in M. Sinclair and G. Valdimarsson, editors. Responsible fisheries in the marine ecosystem. FAO and CABI, Cambridge, Massachusetts, USA.

Turnipseed, M., L. B. Crowder, R. D. Sagarin, and S. E. Roady. 2009. Legal bedrock for rebuilding America's ocean ecosystems. Science 324:183-184.

U.S. Commission on Ocean Policy. 2004. An ocean blueprint for the 21st century; final report of the U.S. Commission on Ocean Policy to the President and Congress. Available online at: http:// oceancommission.gov/documents/full color $\mathrm{rpt} / \mathrm{welcome}$. $\underline{\mathrm{html}}$. 